\title{
Shallow gas hydrates off southwest Taiwan and their mechanisms
}

\author{
Yin-Sheng Huang ${ }^{1} \cdot$ Shu-Kun Hsu ${ }^{1,2}$. Chih-Chieh Su ${ }^{3}$. Andrew Tien-Shun Lin ${ }^{1} \cdot$ Pai-Sen $\mathrm{Yu}^{4} \cdot$ Nathalie Babonneau ${ }^{5}$. \\ Gueorgui Ratzov $^{6}$. Serge Lallemand ${ }^{7} \cdot$ Pi-Chuen Huang ${ }^{1} \cdot$ Shiao-Shan Lin ${ }^{2} \cdot$ Jing-Yi Lin $^{1,2} \cdot$ Kuo-Yen Wei $^{8}$. \\ Yuan-Pin Chang $^{9} \cdot$ Neng-Ti Yu $^{10} \cdot$ Ching-Hui Tsai $^{2}$
}

Received: 5 September 2020 / Revised: 24 January 2021 / Accepted: 29 January 2021 / Published online: 17 February 2021 (c) The Author(s) 2021

\begin{abstract}
We have collected two shallow gas hydrate samples at two sites having different geological settings off southwest Taiwan during the cruise MD214 in 2018. The first core site, MD18-3542, is on the South Yuan-An East Ridge at $1200 \mathrm{~m}$ water deep, where a structural unconformity covered by fine-silt sediments appears at $\sim 5.5 \mathrm{~m}$ below the seafloor. The second core site, MD18-3543, is close to the Good-Weather Ridge at 1100 m water deep, where a gas-related pockmark structure and authigenic carbonates are present at shallow strata with fine-silt sediments near the seafloor. Sediment properties of core MD18-3542 are distinctively different above and below the layer corresponding to the unconformity. Both cores show obvious gaps or voids in the lower core halves. The core features could be linked to the dissociated methane upward migrating from deep strata. Core site settings with upwelling methane would favor the formation of shallow gas hydrates. At site MD18-3542, the shallow hydrate could be formed due to high concentration methane kept beneath the unconformity covered by fine-silt sediments. At site MD18-3543, the shallow hydrate could be formed due to an extremely high flux of upwelling methane trapped either beneath the authigenic carbonates or fine-silt sediments.
\end{abstract}

Keywords MD core $\cdot$ Shallow gas hydrate $\cdot$ Hydrate dissociation $\cdot$ Off SW Taiwan

Shu-Kun Hsu

hsu@ncu.edu.tw

1 Department of Earth Sciences, National Central University, Taoyuan, Taiwan

2 Center for Environmental Studies, National Central University, Taoyuan, Taiwan

3 Institute of Oceanography, National Taiwan University, Taipei, Taiwan

4 Taiwan Ocean Research Institute, Kaohsiung, Taiwan

5 Géosciences Océan, IUEM, Université de Brest, Brest, France

6 Université de Nice Sophia Antipolis, Nice, France

7 Université de Montpellier, Géosciences Montpellier, CNRS, Montpellier, France

8 Department of Geosciences, National Taiwan University, Taipei, Taiwan

9 Department of Oceanography, National Sun Yat-sen University, Kaohsiung, Taiwan

10 Center for General Education, National Tsing Hua University, Hsinchu, Taiwan

\section{Introduction}

Gas hydrates are naturally crystalized substances constructed by gas and water lattices. Gases are trapped by a cage-like structure of water molecules in high pressure and low temperature environments (Kvenvolden 1993; Sloan 1998), such as in the high-latitude permafrost or in the continental margin sediments (Kvenvolden 1993; Kvenvolden and Lorenson 2001). Stable-state gas hydrates could be preserved under a favorable environment. Once the pressure or temperature $(\mathrm{P}-\mathrm{T})$ condition changes, they would become unstable and generate high pressure gases and fluids because of the gas hydrate dissociation. Over the past decades, gas hydrates have drawn much attention for the potential of future alternative-energy. However, they may also cause seabed instability because of the dissociation, and lead to global warming and/or geological hazards (e.g. Kayen and Lee 1991; Kvenvolden 1998; Dillon et al. 2001; Kennett et al. 2003; Best et al. 2006; Nixon and Grozic 2007; Ruppel 2011; Chen et al. 2018; Hsu et al. 2018). Thus, gas hydrates have become an important issue for the impacts on global environments. 
A seismic reflection signal with a reverse polarity subparalleling to the seafloor reflection signal (e.g. Shipley et al. 1979), the bottom simulating reflector (BSR), is generally considered an important indicator for revealing the base of the gas hydrate stability zone. Since the first discovery of the BSR off SW Taiwan, a series of surveys have been completed and the distribution of the BSRs has been mapped (Chi et al. 1998; Schnürle et al. 1999). After that, the BSR distribution map has been refined and the gas hydrate stability zone has been estimated based on more detailed data (Chi et al. 2006; Liu et al. 2006). BSRs are widely distributed over both active and passive continental margins in the offshore area of SW Taiwan (Chi et al. 2006; Liu et al. 2006).

In the passive continental margin of the northern South China Sea, several diving and drilling investigations have been performed. For example, dense chemosynthetic communities were observed on top of the Formosa Ridge by using the ROV (remotely operated vehicle) Hyper-Dolphin, which may indicate the dominance of methane and hydrogen sulfide in that environment (Lin et al. 2007; Machiyama et al. 2007). In situ gas hydrates exposed on the seafloor were also found and measured remotely by using the Raman insertion probe on the ROV Faxian at the ridge (Zhang et al. 2017). In addition, hydrate-bearing sediments have been recovered in the Shenhu Area near the Pearl River Mouth Basin during several drilling expeditions (e.g. Liu et al. 2015; Sha et al. 2015; Zhang et al. 2015).

However, in the active continental margin of the northern South China Sea or off SW Taiwan, a real gas hydrate was never recovered, although natural gas hydrates could be preserved at the water depth deeper than $\sim 650$ meters (m) and the thickness of the gas hydrate stability zone could reach $\sim 600 \mathrm{~m}$ below the seafloor (Hsu et al. 2018). Outside the hydrate stability zone, gas hydrates would be dissociated due to the changing P-T condition. The dissociated gas could migrate upward to shallow strata and seep at the seafloor, escaping to the water column (Hsu et al. 2013, 2018). Large-scale gas emissions (i.e. gas plumes or gas flares) off SW Taiwan have been detected by using high-frequency echograms (Hsu et al. 2013, 2018). The seabed structures such as pockmarks, authigenic carbonates, and submarine mud volcanoes could be linked to the actively upwelling gas (Chen et al. 2010, 2014). In addition, several geophysical (e.g. Cheng et al. 2006; Schnürle et al. 2006), geological (e.g. Horng and Chen 2006; Huang et al. 2006), and geochemical (e.g. Lin et al. 2006; Yang et al. 2006) data have also suggested a high potential of the gas hydrate reserve off SW Taiwan. The estimated volume of the gas hydrate reservoir in the offshore area could be as high as $1.58 \times 10^{12}$ $\mathrm{m}^{3}$ (Chung et al. 2016).

In June 2018, we have conducted an international cooperation cruise under the program, Extreme events Archived in GEological Records (EAGER), between Taiwan and
France by using the R/V Marion Dufresne (MD). During this MD214 cruise (or so-called the EAGER cruise), several MD cores have been collected around Taiwan. In the study, we present the geological characteristics of the two EAGER core sites, MD18-3542 and MD18-3543, where two shallow gas hydrate samples for the first time have been successfully collected off SW Taiwan. We display two deep-towed sub-bottom profilers collected near the core sites by using the R/V Ocean Research 1 (OR1). In addition, we show the core records and discuss their sediment properties. Based on these acoustic data and core records, we propose the probable mechanisms for the formation of the shallow gas hydrate off SW Taiwan.

\section{Materials and methods}

Two marine sediment cores of the study have been collected by using the piston corer CALYPSO during the cruise MD214 off SW Taiwan (Fig. 1). The penetration depth of core MD18-3542 was $\sim 22 \mathrm{~m}$ below the seafloor (mbsf) with the corer of $\sim 25 \mathrm{~m}$ in length. The penetration depth of core MD18-3543 was $\sim 17.5$ mbsf with the corer of only $\sim 14.58$ $\mathrm{m}$ in length, indicating that the whole corer has been plunged into the seafloor before the core recovery. Each core has been divided into ten sections with a length of $1.5 \mathrm{~m}$ for the core analysis, except the last section of each core.

The sub-bottom profiler (SBP) is used to study shallow strata below the seafloor. In this study, two high resolution deep-towed SBPs near core sites MD18-3542 and MD183543 (the blue lines in Fig. 2) were collected by using the deep-towed system Edgetech DW-106 during the cruise OR1-895 in 2009 (Hsu 2009) and the cruise OR1-991 in 2012 (Hsu 2012). These deep-towed SBPs have provided the basis for determining the core sites of the cruise MD214 off SW Taiwan. Acoustic frequency of the SBP system is from 1 to $10 \mathrm{kHz}$ and the vertical resolution is between 9 and $25 \mathrm{~cm}$. The best transmission depths of the acoustic signals reach $\sim 20$ and $\sim 200 \mathrm{mbsf}$ in sand and in mud environments, respectively. Because the deep-towed SBP mainly provides the information of shallow strata, a velocity of $1500 \mathrm{~m} / \mathrm{s}$ was suggested to convert the acoustic travel times into water depths.

Measurements of multi-sensor core logger (MSCL) were performed by using the GEOTEC Standard MSCL system. Each core section was continually measured at an interval of $1 \mathrm{~cm}$, and core-surface photographs of the working-halves were taken after splitting the cores into working- and archive-halves. In addition to the core-surface images, MSCL parameters including magnetic susceptibility, $\mathrm{P}$-waves velocity, $\gamma$-ray density, and electrical resistivity were adopted to study the core materials, which can give the information about the concentration and/or composition 


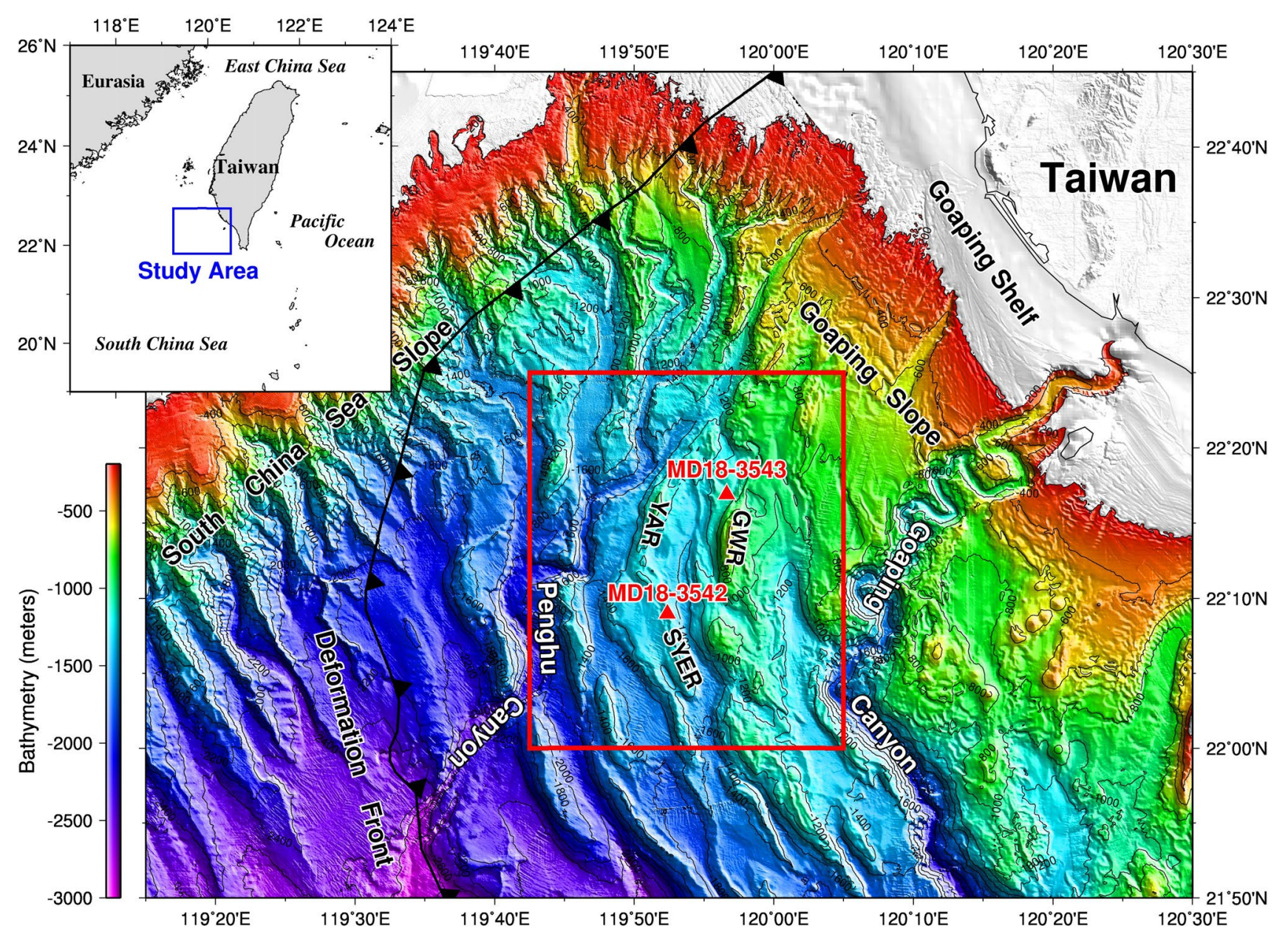

Fig. 1 Bathymetric map showing the major geological structures off SW Taiwan, such as the deformation front, structural ridges, and submarine canyons. Red triangles denote the two core sites collecting shallow hydrate samples during the cruise MD214. Black line with triangles represents the deformation front (Han et al. 2017). Blue square in the upper-left panel marks the study area enlarged in Fig. 1. Red square marks the enlarged area with detailed bathymetry shown in Fig. 2. GWR Good-Weather Ridge, SYER South Yuan-An East Ridge, YAR Yuan-An Ridge of magnetic minerals, compression wave velocity and bulk density of the core materials, and how these core materials oppose to the flow of electric currents.

\section{Site description}

The northeastern portion of the South China Sea is situated at the junction area between the active convergent zone associated with the Luzon Arc-Trench system and the passive continental margin (Fig. 1). The deformation front, defined as the most frontal zone with compression structures such as fold and thrust, is regarded as the separation between the active and passive continental margins (Liu et al. 2004; Yu 2004; Lin et al. 2008; Han et al. 2017). To the west of the deformation front, the passive margin contains several ridges and valleys across the continental slope (Fig. 1). To the east of the deformation front, an accretionary wedge with a series of parallel folds and thrusts, roughly trending north to south (Liu et al. 1997; Lin et al. 2008), has been formed by the convergence between the Eurasian Plate and Philippine Sea Plate. Overall, the offshore area of SW Taiwan is situated in the active continental margin linked to the Manila subduction zone, and is also in the incipient collision zone of the Taiwan orogeny (Lin et al. 2009).

Core site MD18-3542 (Latitude: $22^{\circ} 09.22^{\prime} \mathrm{N}$, Longitude: $\left.119^{\circ} 52.38^{\prime} \mathrm{E}\right)$ is located at the South Yuan-An East Ridge (SYER), to the south of the Yuan-An Ridge, at a water depth of $1240 \mathrm{~m}$, while core site MD18-3543 (Latitude: $22^{\circ} 16.92^{\prime}$ $\mathrm{N}$, Longitude: $119^{\circ} 56.63^{\prime} \mathrm{E}$ ) is located on a pockmark close to the Good-Weather Ridge (GWR) at a water depth of 1138 $\mathrm{m}$ (Fig. 2). These ridges are all regarded as compressional ridges of the fold-and-thrust structure associated with the plate convergence of the Manila subduction zone. 


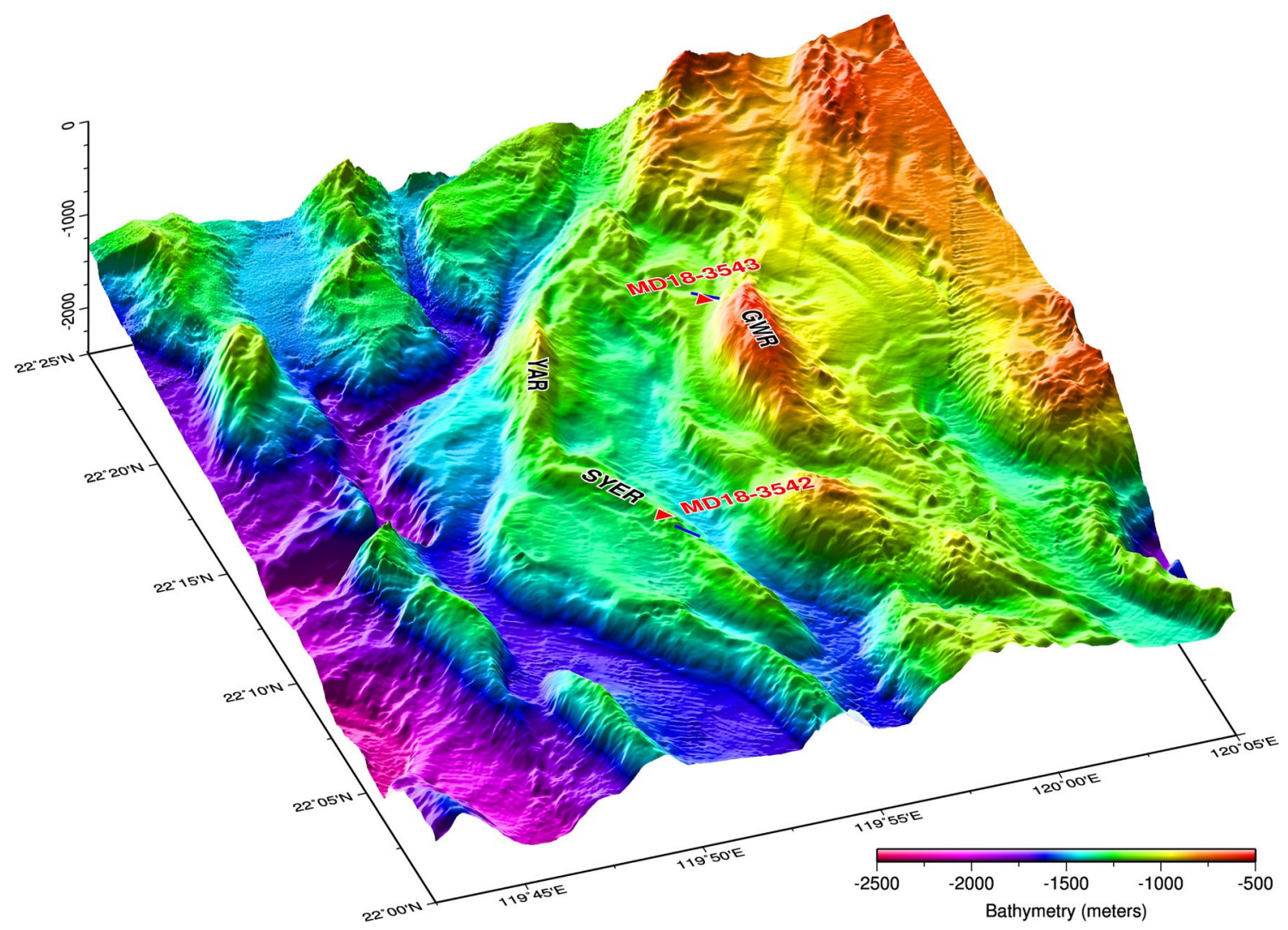

Fig. 2 Detailed bathymetry and regional structures of the study area. Red triangles indicate the core sites MD18-3542 and MD18-3543, where the shallow hydrate samples were collected. Two blue lines

\section{Results}

The two gas hydrate samples were both collected inside the core catchers. The first sample (volume of $\sim 600 \mathrm{~cm}^{3}$; Fig. 3a and c) was obtained at site MD18-3542, and the second one (volume of $\sim 150 \mathrm{~cm}^{3}$; Fig. 3b) was obtained at site MD18-3543. Accompanying with these samples, there was a strong smell of hydrogen sulfide after the core recovery, giving a clear signature that both sites have been affected by free gases (methane and hydrogen sulfide). In the following sections, we will present the deep-towed SBPs and MSCL data of the two core sites to have comprehensive results for further discussion.

\section{High-frequency sub-bottom profiles}

As shown in Fig. 4, a clear top-layer with a thickness of about 5-6 $\mathrm{m}$ exists above a high-reflectance sub-interface at core site MD18-3542 on the SYER. According to the core data (shown in later sections), this top-layer could be composed of fine-grain silt (fine-silt) sediments. Based on the SBP image, the clear sub-interface beneath the top-layer could be illustrated as a structural unconformity, because close to the core sites show the tracks of the deep-towed sub-bottom profiles used in the study. GWR: Good-Weather Ridge; SYER: South Yuan-An East Ridge; YAR: Yuan-An Ridge

there are several inclined-layers below it (Fig. 4b). Hard subbottom properties at the seafloor and near this sub-interface had been expected before the coring because of their strong acoustic reflection signals. However, the corer penetrated through the seafloor and sublayers smoothly, implying that the underlying layers (shallower than $\sim 20 \mathrm{mbsf}$ ) are almost composed of low-strength materials (e.g. loose sediments).

At core site MD18-3543 near the GWR, similar to the coring at site MD18-3542, the corer penetrated into the seabed completely, also indicating low-strength materials beneath the site. A top-layer and the unconformity also appear in this area, but their signals become relatively blurred beneath core site MD18-3543 (Fig. 5). Hsu et al. (2014) have pointed out some gas-related structures such as pockmarks and authigenic carbonates at the seafloor and shallow strata by using the deep-towed SBP, showing that this site has been significantly disturbed by upwelling gases. Below the core site, the acoustic signals in the SBP image are relatively weak at shallow layers but some reflection signals remain strong (Fig. 5b). The weak signals could be attributed to the presence of free gases at this gas-activity site. In contrast, the high-reflectance signals could be suggested as highstrength materials such as authigenic carbonates caused 
Fig. 3 a The gas hydrate sample collected at core site MD18-3542, and b the sample collected at core site MD183543. c The burning gas hydrate obtained at core site MD183542. The person who holds the burning gas hydrate is Prof. Shu-Kun Hsu, and next to him is Prof. Chih-Chieh Su

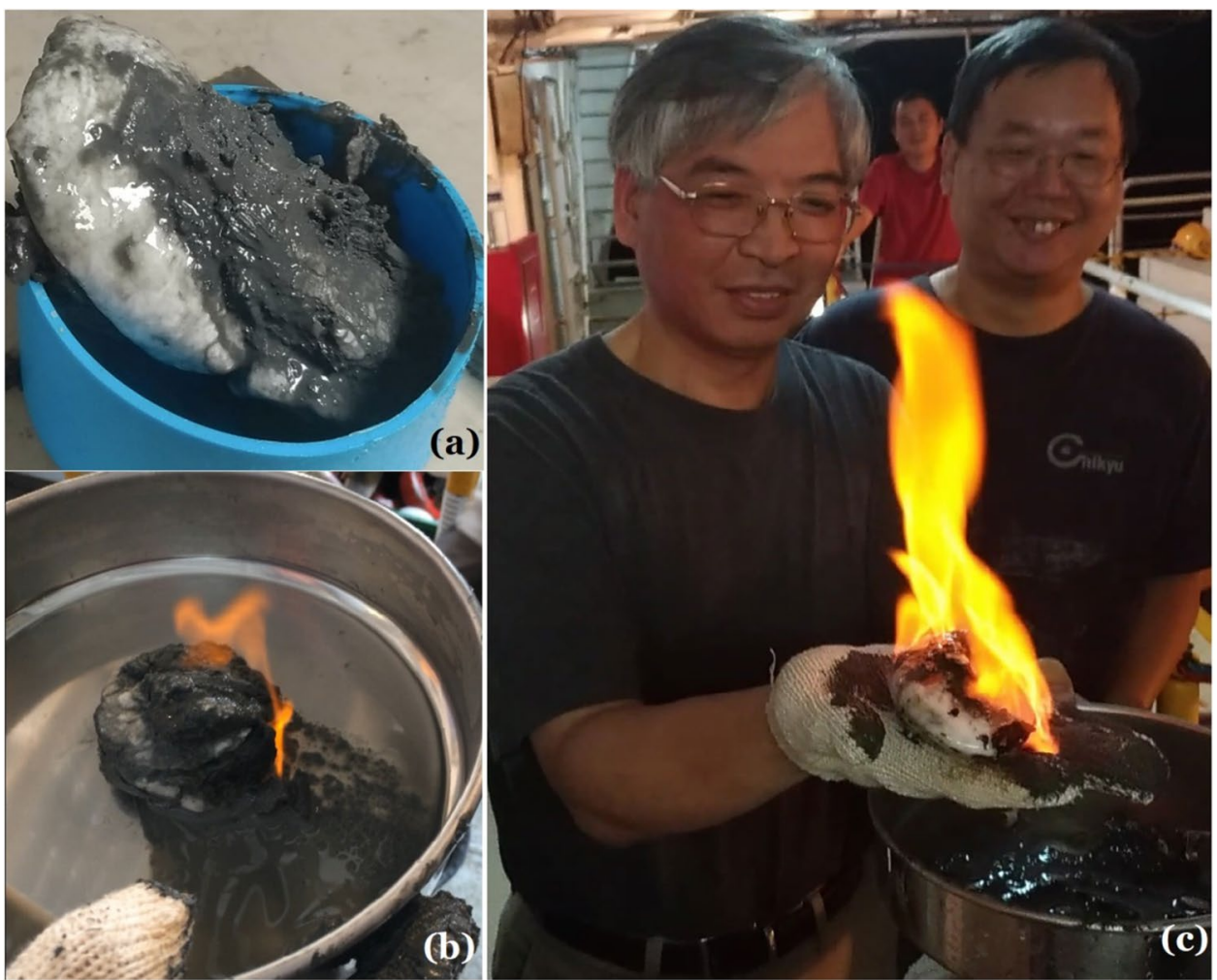

by the interaction between methane and sulfate (Hsu et al. 2014). Another interpretation is that the high-reflectance signals could be simply interpreted as harder sublayers (in comparison to the layers with free gases) that have also been disturbed by upwelling gases.

\section{Core MD18-3542}

Core MD18-3542 is $15 \mathrm{~m}$ in length. Based on the core descriptions and surface images of the working-halves, most core sediments are homogeneously composed of dark-green or dark-grey fine-silts with some small bubbles (Fig. 6). No clearly sandy or turbidity layers are observed, but some thin and dark laminations appear in the upper sections of the core. Also, water contents look higher in the upper sections, especially in the first section (0 to $150 \mathrm{~cm}$ ). Strikingly, many sediment gaps and voids appear in the lower half of the core (Fig. 6), which could be ascribed to the sediment expansion during the piston core recovery.

One of the most distinctive features of the MSCL records is the sharp drop of the magnetic susceptibility (MS) value from $\sim 30 \times 10^{-5}$ to $\sim 17 \times 10^{-5}$ SI near the depth of $\sim 3.5 \mathrm{~m}$ (Fig. 6). Such clear MS anomaly may indicate the significant change of the dominant magnetic mineralogy in the core sediments (unpublished data). For example, detrital magnetite could be replaced by authigenic iron sulfides such as pyrrhotite, greigite, and pyrite in a methane-rich environment (e.g. Horng and Chen 2006; Horng et al. 2016; Horng 2018;
Huang et al. 2019). P-wave velocity shows dramatic value fluctuations, particularly below the depth of $\sim 5.5 \mathrm{~m}$ (Fig. 6), although the record seems relatively unreliable. Likewise, the average of the resistivity values displays an obvious increase from $\sim 0.5$ to $\sim 0.8 \mathrm{Ohm}-\mathrm{m}$ near the same location. These changes of the sediment properties imply that the free gas has existed mainly below $\sim 5.5 \mathrm{~m}$ core depth, coinciding with the layer where the unconformity appears in the SBP image (Fig. 4b). In addition, because the MS anomaly (at $\sim 3.5 \mathrm{~m}$ core depth) is found above this gas-affected zone, some methane should have leaked to the upper layers. As for the $\gamma$-ray density, the values range from $\sim 1.6$ to $\sim 1.8 \mathrm{~g} /$ cc. However, we do not find obvious change related to the mentioned anomaly, except the endpoints between every two core sections (Fig. 6).

\section{Core MD18-3543}

The length of core MD18-3543 is $13.9 \mathrm{~m}$. Similar to the composition of core MD18-3542, most sediments of core MD18-3543 are also homogeneously composed of darkgreen or dark-grey fine-silts without clearly sandy or turbidity layers above the core depth of $\sim 5.8 \mathrm{~m}$ (Fig. 7). Below the depth, many obvious voids appear in the core. Because this core was exactly collected at a pockmark structure where the gas influence should be still active (Hsu et al. 2014), free gases might have migrated into shallow layers. Thus, 

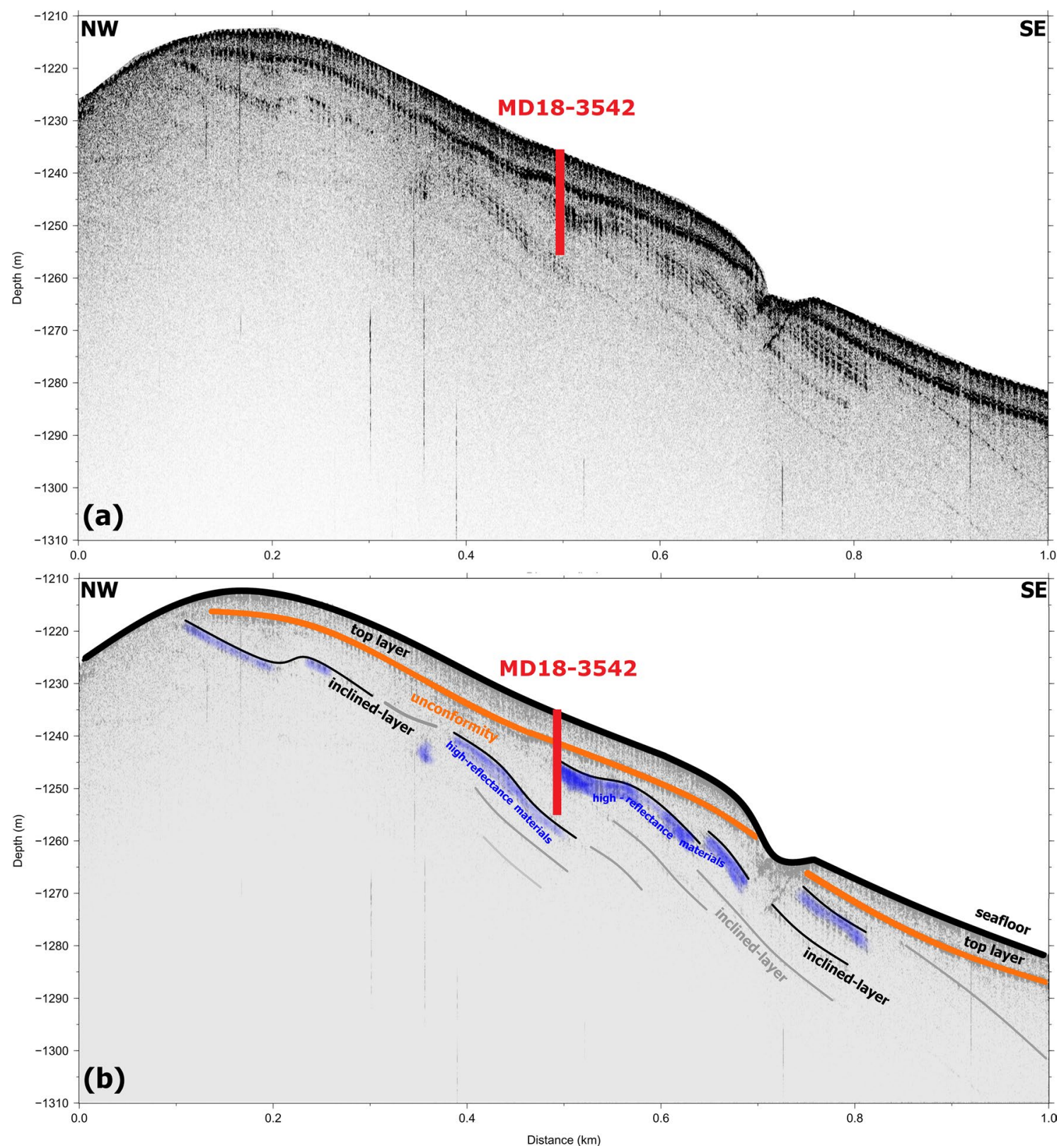

Fig. 4 a Acoustic image of the deep-towed sub-bottom profile (SBP) close to core site MD18-3542. b The illustration of the major structures of the SBP image. Red rectangular represents core MD18-3542.

the obvious voids could also be attributed to the expansion of the gas-bearing sediments after the piston core recovery.

Variation of the MSCL records in the upper half of the core is overall similar to that of core MD18-3542 (Figs. 6 and 7), suggesting a similar formation of the modern fine-silty layers in the area. In the lower half of the core, the records are discontinuous and less reliable due to the presence of the voids. However, this signature could reveal that the core site has been significantly disturbed by the upwelling gas. For example, although the P-wave velocity of the core is not reliable, the
The orange sub-interface indicates the unconformity. Those highreflectance materials beneath the inclined-layers are marked in blue

layer where the values fluctuate dramatically might mark the uppermost location affected by free gases. This gas-affected layer coincides with that presented in the deep-towed SBP image. 

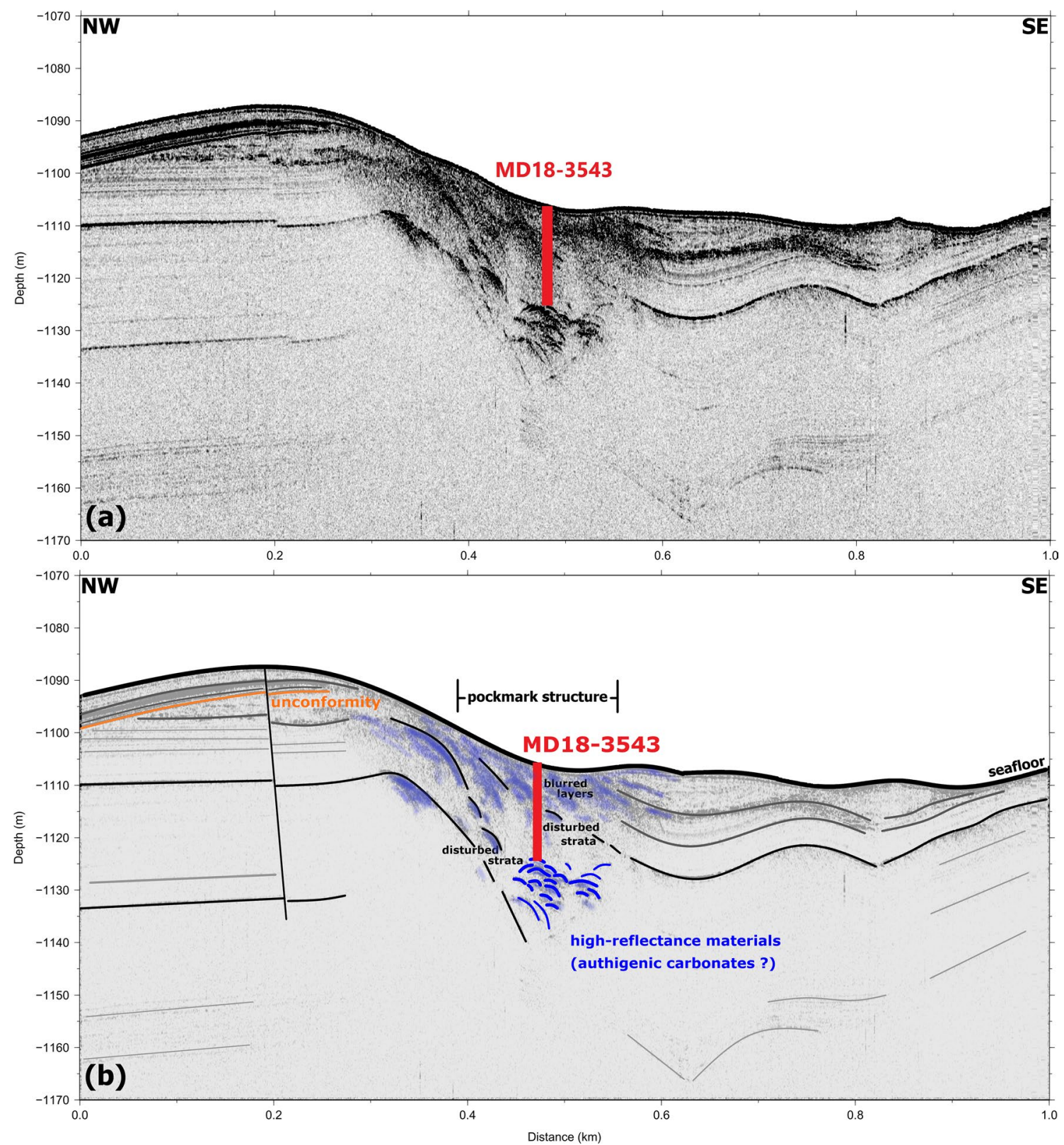

Fig. 5 a Acoustic image of the deep-towed sub-bottom profile (SBP) close to core site MD18-3543. b The illustration of the major structures of the SBP image. Red rectangular represents core MD18-3543.

\section{Discussion}

Shallow gas hydrates are not common but they may occur at sites with strong gas activity (e.g. Bahr et al. 2010; Dondurur et al. 2011; Wei et al. 2015). The reason for few shallow gas hydrates may be due to insufficient methane concentration in shallow layers. In the offshore area of SW Taiwan, Hsu et al. (2013) have suggested a very high flux of upwelling methane probably caused by the dissociated hydrate. However, if the free methane cannot be kept beneath the seafloor, it would eventually escape out of the seabed and form gas plumes
The orange sub-interface indicates the unconformity. High-reflectance materials beneath the core site are marked in blue

(Hsu et al. 2018). Because our hydrate samples were both obtained at shallow layers, it is essential to understand the mechanisms that have formed shallow gas hydrates off SW Taiwan.

\section{Shallow gas hydrates formed beneath a structural unconformity}

As shown in Fig. 4, core MD18-3542 has penetrated the unconformity near $\sim 5.5 \mathrm{mbsf}$ and a set of high-reflectance inclined strata exist under the unconformity. These inclined 
Fig. 6 Information of core MD18-3542 including the core-surface image, magnetic susceptibility (MS), P-wave velocity (P-wave VEL), $\gamma$-ray density (Density), and resistivity values

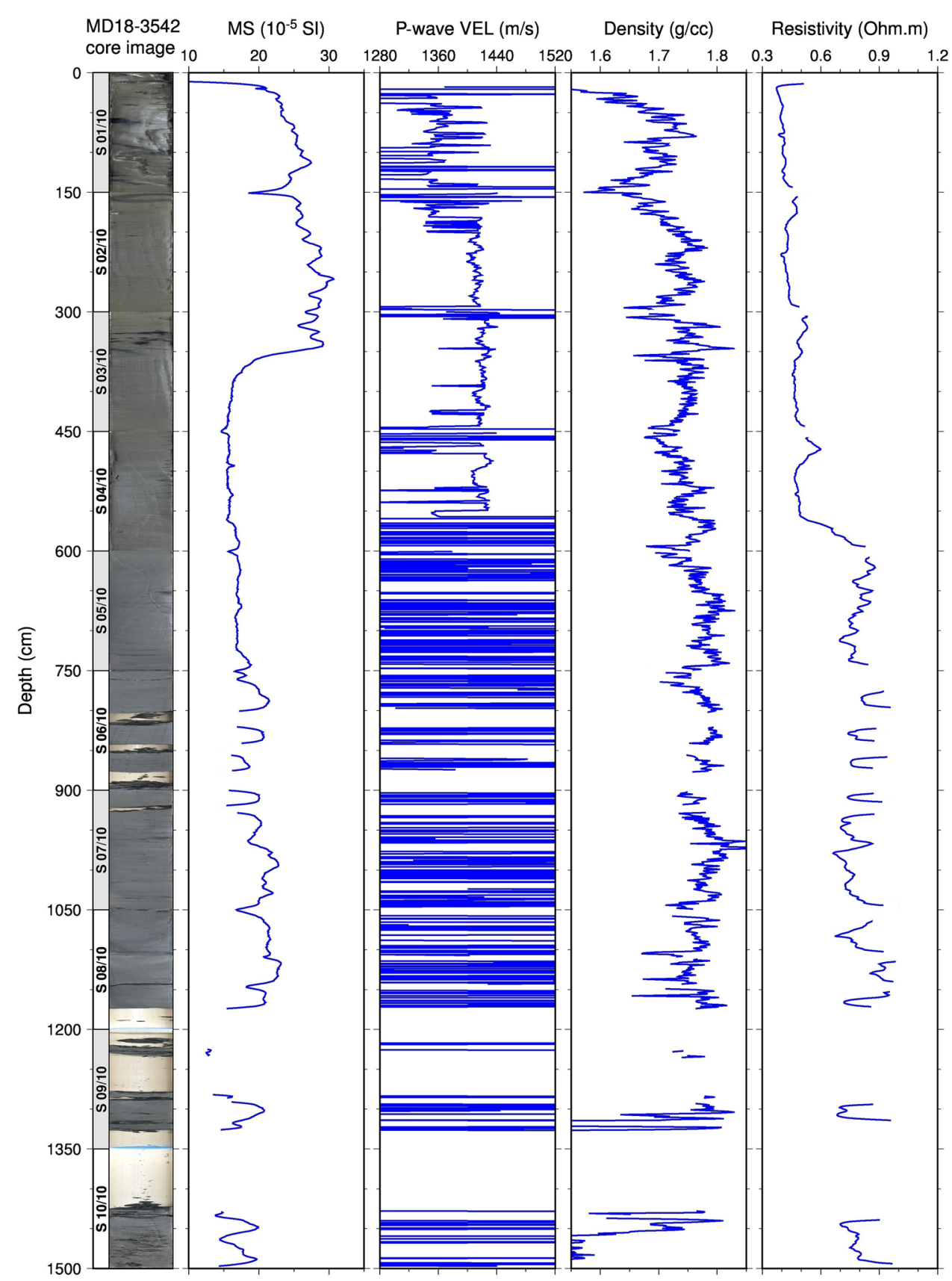

strata could be generally interpreted as higher porous layers (such as sandy layers) interbedded with muddy sediments. In that case, dissociated methane at depth could migrate upward along these inclined strata or through fissures, and finally been trapped and concentrated below the unconformity covered by the fine-silty cap-layer (Fig. 8a). If the P-T condition is favorable, such high concentration methane could benefit the formation of shallow gas hydrates beneath the unconformity.

Figure 8a shows that the shallow gas hydrate could be formed right beneath the unconformity if the methane could be highly concentrated. However, one gas hydrate sample was only collected in the core catcher. A simple interpretation is that once the core head hit the "rigid" hydrate layer, the corer would stop penetrating. As a result, the hydratebearing sediment was clogged inside the core catcher (core head). The sediment collected by the core-pipe would be pulled and broken due to the suction force of the piston during the core recovery in addition to the gas expansion. That may explain why several voids are present in the lower half of the core. As for those voids inside core MD18-3543, the cause could be the same. In addition, because there is no clear soupy-like texture observed in both cores, these voids should be unrelated to the gas hydrate dissociation. 
Fig. 7 Information of core MD18-3543 including the core-surface image, magnetic susceptibility (MS), P-wave velocity (P-wave VEL), $\gamma$-ray density (Density), and resistivity values

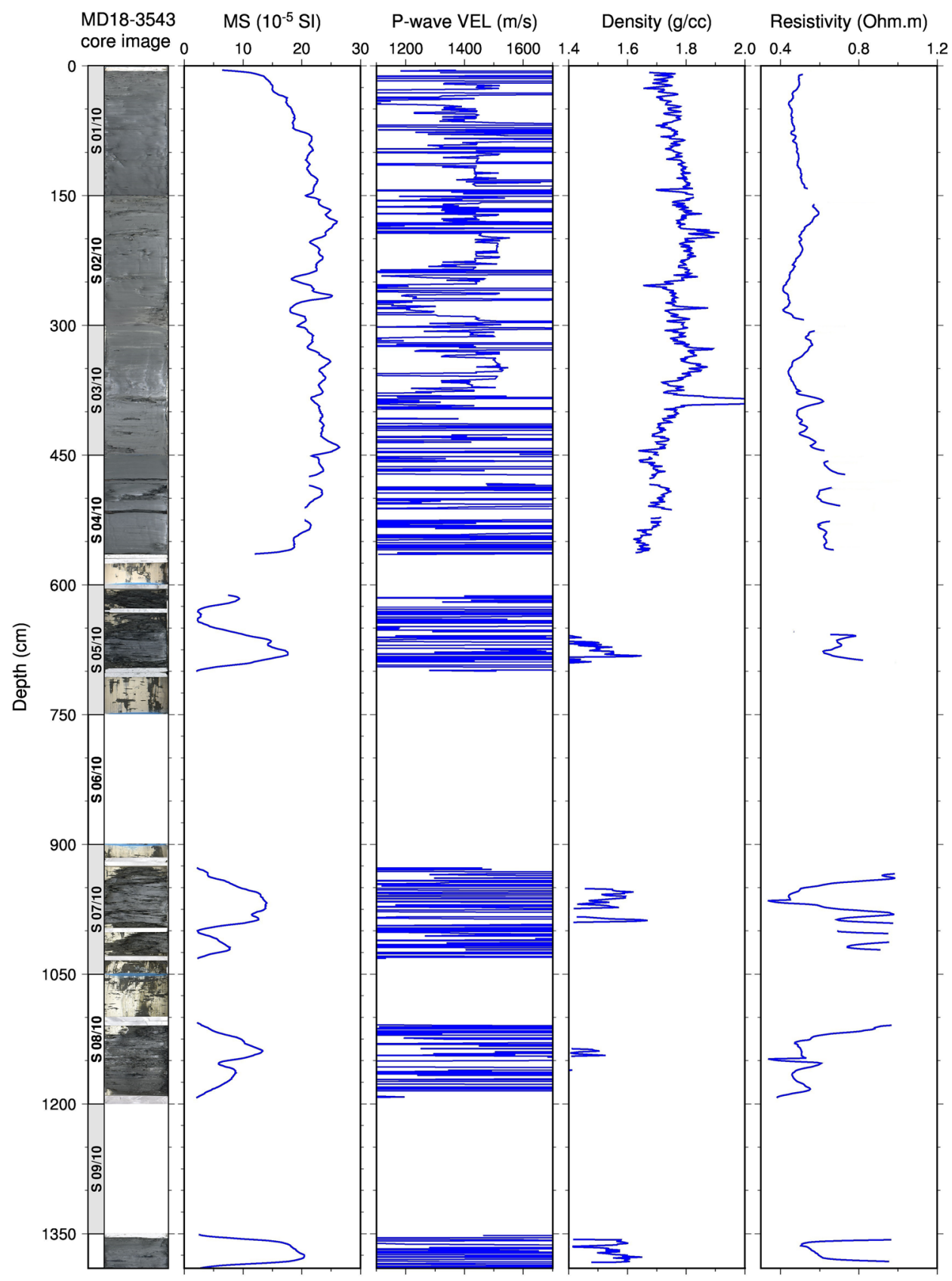

\section{Shallow gas hydrates formed in a setting of high- flux methane}

The gas hydrate sample at site MD18-3543 is collected at a pockmark structure (Fig. 5). The pockmark structure has a distinctively morphological feature and strong backscattering signatures near the seafloor (Hsu et al. 2014). The forming of a pockmark indicates that a very high flux of upwelling methane (or gases) has blown out of the seafloor, and caused a concavely crater-like structure at seabed (Hsu et al. 2014). As shown in Fig. 5, several highreflectance materials are observed within the pockmark structure, which could be interpreted as either gas-disturbed silt layers or authigenic carbonates resulting from the reaction between upwelling methane and surrounding sulfates. Although there is no clear cap-layer like that at site MD18-3542, shallow gas hydrates do appear at this high-gas-flux site MD18-3543. If the upward flux of free methane is strong enough, those authigenic carbonates or disturbed silt sediments might still play a role to keep and concentrate the upwelling methane (Fig. 8b). Thus, we suggest that shallow gas hydrates could exist at a site where the upward methane flux is very high. 


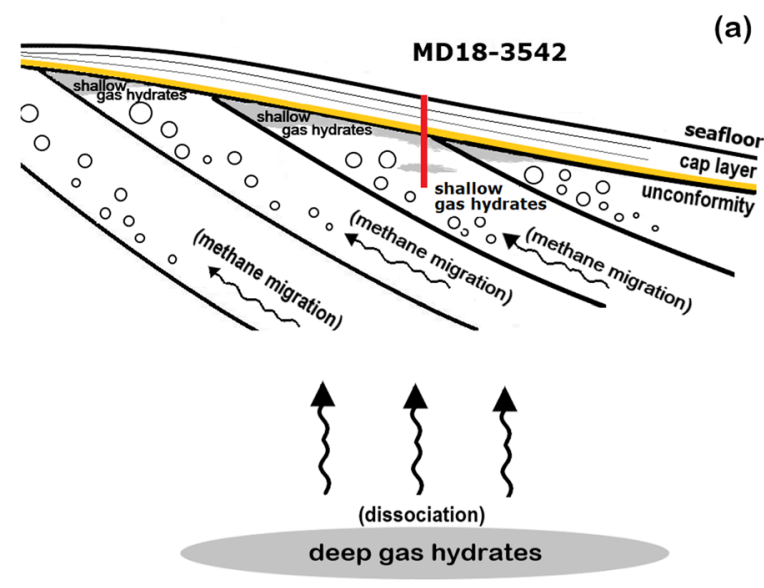

Fig. 8 Schematic models illustrate the formations of the shallow gas hydrates: a the case at core site MD18-3542 and b the case at core site MD18-3543. Gray areas point out the gas hydrate reservoir at depth and shallow gas hydrate areas. Red rectangles indicate the two cores. Bubbles and arrows represent the upward migration of free

\section{Conclusions}

We have collected two shallow gas hydrate samples at two sites having different geological settings during the cruise MD214 off SW Taiwan. Core site MD18-3542 is located at the South Yuan-An East Ridge, where a structural unconformity exists at the depth of $\sim 5.5 \mathrm{mbsf}$, and the sediment properties are different above and below this unconformity. Core site MD18-3543 is located near the Good-Weather Ridge, where a gas-related pockmark structure and authigenic carbonates appear at the seafloor and shallow layers. Obvious gaps or voids are observed in the lower halves of both cores, suggesting that the core sediment has been pulled and severed due to the suction force of the piston core recovery at these gas activity sites. Two geological settings could be favorable for the formation of the shallow gas hydrate off SW Taiwan. Firstly, like core site MD18-3542, the finesilt sediments over the angular unconformity could act as cap-layers to keep and concentrate the upward migrating methane. Secondly, like core site MD18-3543, authigenic carbonates or some disturbed silt layers could also play the role as certain cap-structures, if the upwelling methane flux is very high.

Acknowledgements We would like to express our gratitude to the shipboard scientific parties and the crews of the R/V Marion Dufresne, operated by Institut français de recherche pour l'exploitation de la mer (Ifremer), to collect the cores during the MD214/EAGER cruise. We thank members of the Marine Core Repository Laboratory in Taiwan Ocean Research Institute (TORI) for core analysis, storage and management. We are grateful to Dr. Song-Chuen Chen for constructive discussion and providing some geophysical data under the project of gas-hydrate investigation conducted by Central Geological Survey (CGS), Ministry of Economic Affairs of Taiwan. Constructive reviews by Dr. Philippe Schnürle and an anonymous reviewer greatly improve

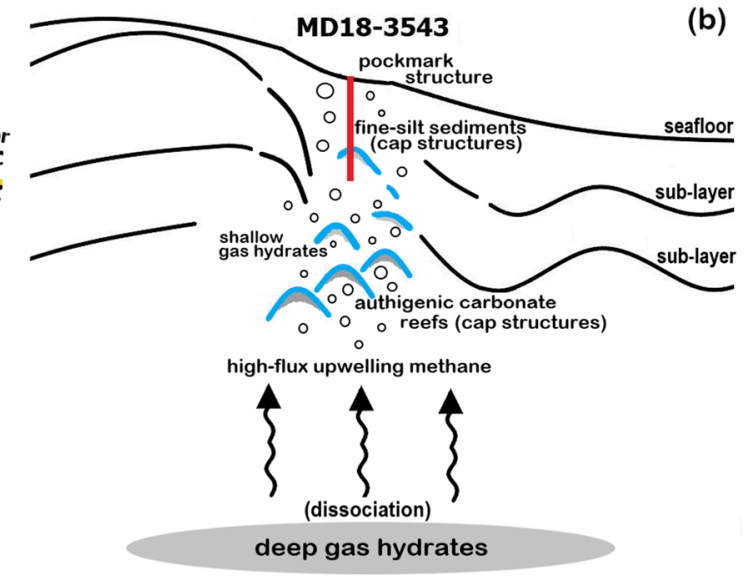

methane and its migration direction. Different colors show two structural traps to keep free methane: the unconformity of a fine-silt caplayer is marked in yellow; authigenic carbonates and disturbed finesilt sediments acting as cap-structures are marked in blue (see the text in more detail)

the manuscript. The MD214/EAGER cruise was partially funded by the National Energy Program-Phase II (NEPII) project of Ministry of Science and Technology (MOST) of Taiwan and largely supported by the International Research Project (IRP): From Deep Earth to Extreme Events (D3E) between Centre national de la recherche scientifique (CNRS) of France and MOST of Taiwan. Figures were plotted by using the software GMT (Wessel and Smith 1998).

Open Access This article is licensed under a Creative Commons Attribution 4.0 International License, which permits use, sharing, adaptation, distribution and reproduction in any medium or format, as long as you give appropriate credit to the original author(s) and the source, provide a link to the Creative Commons licence, and indicate if changes were made. The images or other third party material in this article are included in the article's Creative Commons licence, unless indicated otherwise in a credit line to the material. If material is not included in the article's Creative Commons licence and your intended use is not permitted by statutory regulation or exceeds the permitted use, you will need to obtain permission directly from the copyright holder. To view a copy of this licence, visit http://creativecommons.org/licenses/by/4.0/.

\section{References}

Bahr A, Pape T, Abeg F, Bohrmann G, van Weering T, Ivanov MK (2010) Authigenic carbonates from the eastern Black Sea as an archive for shallow gas hydrate dynamics-Results from the combination of CT imaging with mineralogical and stable isotope analyses. Mar Pet Geol 27:1819-1829

Best AI, Richardson MD, Boudreau BP, Judd AG, Leifer I, Lyons AP, Martens CS, Orange DL, Wheeler SJ (2006) Shallow seabed methane gas could pose coastal hazard. EOS Tran AGU $87: 213-217$

Chen SC, Hsu SK, Tsai CH, Ku CY, Yeh YC, Wang Y (2010) Gas seepage, pockmarks and mud volcanoes in the near shore of SW Taiwan. Mar Geophys Res 31:133-147

Chen SC, Hsu SK, Wang Y, Chung SH, Chen PC, Tsai CH, Liu CS, Lin HS, Lee YW (2014) Distribution and characters of the mud 
diapirs and mud volcanoes off southwest Taiwan. J Asian Earth Sci 92:201-204

Chen SC, Tsai CH, Hsu SK, Yeh YC, Liu CS, Chung SH, Wei CY (2018) Fangliao Slide-a large slope failure in the upper Kaoping Slope off southwest Taiwan. Terr Atmos Ocean Sci 29:17-30

Cheng WB, Lee CS, Liu CS, Schnürle P, Lin SS, Tsai HR (2006) Velocity structure in marine sediments with gas hydrate reflectors in offshore SW Taiwan, from OBS data tomography. Terr Atmos Ocean Sci 17:739-756

Chi WC, Reed DL, Liu CS, Lundberg N (1998) Distribution of the bottom-simulating reflector in the offshore Taiwan collision zone. Terr Atmos Ocean Sci 9:779-794

Chi WC, Reed DL, Tsai CC (2006) Gas hydrate stability zone in offshore southern Taiwan. Terr Atmos Ocean Sci 17:829-843

Chung SH, Lin AT, Lin CC, Liu CS, Chen SC, Wang Y, Wei CY, Chen PC (2016) Geological investigation of gas hydrate resource potential in the offshore areas of South-Southwest Taiwan. Spec Publ Cent Geol Surv 30:1-42 (In Chinese with English abstract)

Dillion WP, Nealon JW, Taylor MH, Lee MW, Drury RM, Anton CH (2001) Seafloor collapse and methane venting associated with gas hydrate on the Blake Ridge-Causes and implications to seafloor stability and methane release. In: Paull CK, Dillon WP (eds) Natural gas hydrates: occurrence, distribution, and detection. Geophysical monograph 124, AGU Was D.C., pp 211-233

Dondurur D, Çifçi G, Drahor MG, Coskun S (2011) Acoustic evidence of shallow gas accumulations and active pockmarks in the Izmir Gulf, Aegean Sea. Mar Pet Geol 28:1505-1516

Han WC, Liu CS, Chi WC, Chen L, Lin CC, Chen SC (2017) Westward advance of the deformation front and evolution of submarine canyons offshore of southwest Taiwan. J Asian Earth Sci 149:6-19

Hsu SK (2009) Geological investigation of natural gas hydrates in the offshore area of southwest Taiwan: Multi-bean bathymetry and high-resolution sonar (2/4). Report of Central Geological Survey 98 - 24, pp 221 (In Chinese with English abstract)

Hsu SK (2012) Geological investigation of natural gas hydrates in the offshore area of southwest Taiwan: High-resolution sonar (1/4). Report of Central Geological Survey 101 - 23, pp 142 (In Chinese with English abstract)

Hsu SK, Wang SY, Liao YC, Yang TF, Jan S, Lin JY, Chen SC (2013) Tide-modulated gas emissions and tremors off SW Taiwan. Earth Planet Sci Lett 369-370:98-107

Hsu SK, Chiang CW, Evans RL, Chen CS, Chiu SD, Ma YF, Chen SC, Tsai CH, Lin SS, Wang Y (2014) Marine controlled source electro-magnetic method used for the gas hydrate investigation in the offshore area of SW Taiwan. J Asian Earth Sci 92:224-232

Hsu SK, Lin SS, Wang SY, Tsai CH, Doo WB, Chen SC, Lin JY, Yeh YC, Wang HF, Su CW (2018) Seabed gas emissions and submarine landslides off SW Taiwan. Terr Atmos Ocean Sci 29:7-15

Horng CS, Chen KH (2006) Complicated magnetic mineral assemblages in marine sediments offshore of southwestern Taiwan: possible influence of methane flux on the early diagenetic process. Terr Atmos Ocean Sci 17:1009-1026

Horng CS (2018) Unusual magnetic properties of sedimentary pyrrhotite in methane seepage sediments: comparison with metamorphic pyrrhotite and sedimentary greigite. J Geophys Res 123:4601-4617

Horng CS, Chen KH, Lin CH, Tseng CY, Wang Y, Fei LY, Chung SH, Chen SC, Chen PC, Wei CY, Wang CC (2016) Rock magnetic properties of sediments in gas hydrate-bearing potential area offshore of southwestern Taiwan. Spec Publ Cent Geol Surv 30:89-122 (In Chinese with English abstract)

Huang CY, Chien CW, Zhao M, Li HC, lizuka Y (2006) Geological study of active cold seeps in the syn-collision accretionary prism Kaoping Slope off SW Taiwan. Terr Atmos Ocean Sci 17:679-702
Huang YS, Su CC, Doo WB, Hsu SK, Tsai CH, Wang HF, Lin SS, Liang CW, Lin JY, Chen JE, Lin YJ, Wang Y (2019) Hydrothermal activity revealed by rock magnetic anomaly from core sediments in the southern Okinawa Trough. Terr Atmos Ocean Sci 30:685-694

Kayen RE, Lee HJ (1991) Pleistocene slope instability of gas hydrateladen sediment on the Beaufort Sea margin. Mar Geotechnol 10:125-141

Kennett JP, Cannaritao KG, Hendy IL, Behl RJ (2003) Methane hydrates in Quaternary climate change: the clathrate gun hypothesis. Spec Publ Ser Vol 54, AGU Wash D.C

Kvenvolden KA (1993) Gas hydrates-geological perspective and global change. Rev Geophys 31:173-187

Kvenvolden KA (1998) A primer on the geological occurrence of gas hydrate. In: Henniet JP, Mienert J (eds) Gas hydrates: relevance to world margin stability and climate change. Geological Society, London, pp 9-30

Kvenvolden KA, Lorenson TD (2001) The global occurrence of natural gas hydrate. Geophys Monograph 124:3-18

Lin S, Hsieh WC, Lim YC, Yang TF, Liu CS, Wang Y (2006) Methane migration and its influence on sulfate reduction in the Good Weather Ridge region, South China Sea continental margin sediments. Terr Atmos Oceanic Sci 17:883-902

Lin S, Lim YC, Liu CS, Yang TF, Chen YG, Machiyama H, Soh W, Fujikura K (2007) Formosa Ridge, a cold seep with densely populated chemosynthetic community in the passive margin, southwest of Taiwan. Geochim Cosmochim Acta 71(Supplement1):A582

Lin AT, Liu CC, Lin CC, Schnürle P, Chen GY, Liao WZ, Teng LS, Chuang HJ, Wu WS (2008) Tectonic features associated with the overriding of an accretionary wedge on top of a rifted continental margin: an example from Taiwan. Mar Geol 255:186-203

Lin AT, Yao B, Hsu SK, Liu CS, Huang CY (2009) Tectonic features of the incipient arc-continent collision zone of Taiwan: implications for seismicity. Tectonophysics 479:28-42

Liu CS, Huang IL, Teng LS (1997) Structural features off southwestern Taiwan. Mar Geol 137:305-319

Liu CS, Deffontaines B, Lu CY, Lallemand S (2004) Deformation patterns of an accretionary wedge in the transition zone from subduction to collision offshore southwestern Taiwan. Mar Geophys Res 25:123-137

Liu CS, Schnurle P, Wang YS, Chung SH, Chen SC, Hsiuan TH (2006) Distribution and characters of gas hydrate offshore of southwestern Taiwan. Terr Atmos Oceanic Sci 17:615-644

Liu C, Meng Q, He X, Li C, Ye Y, Zhang G, Liang J (2015) Characterization of natural gas hydrate recovered from Pearl River Mouth basin in South China Sea. Mar Pet Geol 61:14-21

Machiyama H, Lin S, Fujikura K, Huang CY, Ku CY, Lin LH, Liu CS, Morita S, Nunoura T, Soh W, Toki T, Yang TF (2007) Discovery of "hydrothermal" chemosynthetic community in a cold seep environment, Formosa Ridge: seafloor observation results from first ROV cruise, off southwestern Taiwan. EOS Trans AGU 88(52): OS23A-1041

Nixon MF, Grozic JL (2007) Submarine slope failure due to gas hydrate dissociation. Can Geotech J 44:314-325

Ruppel CD (2011) Methane hydrates and contemporary climate change. Nat Educ Knowl 3(10):29

Schnürle P, Hsiuan DH, Liu CS (1999) Constrains on free gas and gas hydrate bearing sediments from multi-channel seismic data, offshore south-western Taiwan. Petrol Geol Taiwan 33:21-42

Schnürle P, Liu CS, Lee CS (2006) Acoustic and shear-wave velocities in hydrate-bearing sediments offshore southwestern Taiwan: tomography, converted waves analysis and reverse-time migration of OBS records. Terr Atmos Oceanic Sci 17:757-779 
Sha Z, Liang J, Zhang G, Yang S, Lu J, Zhang Z et al (2015) A seepage gas hydrate system in northern South China Sea: seismic and well log interpretations. Mar Geol 366:69-67

Shipley TH, Houston MH, Buffler RT, Shaub FJ, McMillen KJ, Ladd JW, Worzel JL (1979) Seismic reflection evidence for widespread occurrence of possible gas- hydrate horizons on continental slopes and rises. AAPG Bull 63:2204-2213

Sloan ED (1998) Gas hydrates: relevance to world margin stability and climate change. In: Henriet JP, Mienert J (eds) Geological society. Special Publications, London

Wei J, Pape T, Sultan N, Colliat JL, Himmler T, Ruffine L, de Prunele A, Dennielou B, Garziglia S, Marsset T, Peters CA, Rabiu A, Bohrmann G (2015) Gas hydrate distributions in sediments of pockmarks from the Nigerian margin-Results and interpretation from shallow drilling. Mar Pet Geol 59:359-370

Wessel P, Smith WHF (1998) New improved version of generic mapping tools released. EOS Trans AGU 79:579

Yang TF, Chuang PC, Lin S, Chen JC, Wang Y, Chung SH (2006) Methane venting in gas hydrate potential area offshore of SW
Taiwan: evidence of gas analysis of water column samples. Terr Atmos Oceanic Sci 17:933-950

Yu HS (2004) Nature and distribution of the deformation front in the Luzon Arc-Chinese continental margin collision zone at Taiwan. Mar Geophys Res 25:109-122

Zhang G, Liang J, Lu J, Yang S, Zhang M, Holland M, Schultheiss P, Su X, Sha Z, Xu H, Gong Y, Fu S, Wang L, Kuang Z (2015) Geological features, controlling factors and potential prospects of the gas hydrate occurrence in the east part of the Pearl River Mouth Basin, South China Sea. Mar Pet Geol 67:356-367

Zhang X, Luan DZ, Wang Z, Xi X, Wang S, Li B, Lina F, Yan C (2017) In situ Raman detection of gas hydrates exposed on the seafloor of the South China Sea. Geochem Geophys Geosyst 18:3700-3713

Publisher's note Springer Nature remains neutral with regard to jurisdictional claims in published maps and institutional affiliations. 